\title{
PERTUMBUHAN NEGARA SEKUNDER
}

\author{
Aziz Alhuda \\ alhuda.aziz03@gmail.com \\ 2010003600236 \\ Universitas Ekasakti
}

\section{A. PENDAHULUAN}

Manusia memiliki ketergantungan dalam menjalani hidup antara satu dengan yang lainnya, sehingga ini telah memberikan peluang untuk terjadinya interaksi yang secara alamiah dapat membentuk komunitas di suatu wilayah. Wilayah tersebut dapat berupa sebuah daratan saja maupun wilayah yang juga meliputi daratan dan lautan. Komunitas yang dikatakan di atas merupakan landasan dasar dari terbentuknya sebuah Negara. Lahirnya negara, seperti halnya yang terjadi pada era kemerdekaan Indonesia. Definisi negara tidak bisa hanya didefinisikan pada sebuah ikatan perjanjian oleh masyarakat. Definisi negara pada era kemerdekaan tidak hanya membutuhkan perjanjian, melainkan juga membuthkan sebuah pengakuan dari negara lain terkait kejelasan dalam wilayah negara, adanya penduduk dan legitimasi pemerintahan.

Di sini jelas sekali bahwa terkait dengan definisi negara memang seharusnya setiap masa terdapat penyesuaian terhadap kondisi dan kebutuhan. Model dan bentuk pengertian negara yang demikian akan melahirkan adanya definisi Negara yang akan berubah-ubah pada setiap masa. Perubahan tersebut nantinya juga dapat terjadi pada masa yang akan datang. Pengertian Negara tidak hanya suatu wilayah dengan penduduk yang memiliki kesamaan paham untuk membentuk pemerintahan dengan didukung oleh 
pengakuan dari negara lain, akan tetapi bisa juga ditambah lagi dengan adanya istilah pengakuan dari lembaga internasional (seperti contohnya Perserikatan Bangsa-Bangsa). Kebutuhan untuk mendapatkan pengakuan dari Perserikatan Bangsa-Bangsa menjadi suatu kewajiban yang wajib untuk dimiliki dan menjadi suatu hal yang penting, karena dengan pengakuan Perserikatan Bangsa-Bangsa tersebut Negara menjadi benar-benar dianggap ada dan penindasan yang dilakukan oleh Negara lain menjadi tidak dibenarkan.

Pertumbuhan negara terbagi menjadi dua yaitu pertumbuhan negara secara primer dan pertumbuhan negara secara sekunder. Pertumbuhan negara secara primer merupakan sebuah kajian terhadap pertumbuhan negara yang dimulai dari masyarakat primitive (sederhana) hingga masyarakat modern, sedangkan pertumbuhan negara secara sekunder merupakan sebuah kajian terkait bagaimana terjadinya sebuah negara baru yang bukan merupakan negara pertama. Terdapat beberapa macam dari asal mula terjadinya negara sekunder, yaitu adanya proklamasi, separatis (pemisahan), anexatie (penguasaan/pencaplokan), innovation (pembentukan baru), acessie (penarikan), cessie (penyerahan), fusi (peleburan), occupatie (pendudukan) serta pendudukan di wilayah yang belum terdapat kepemerintahan sebelumnya. Negara yang sudah ada ini mengalami perubahan bentuk dan susunannya menjadi negara yang lain pula. Negara Republik Indonesia merupakan negara yang terbentuk secara sekunder. Pada kenyataannya negara yang terbentuk secara sekunder ini tidak bisa untuk dipungkiri, meskipun cara dari terbentuknya bisa dikatakan tidak sah menurut hukum.

Berdasarkan latar belakang di atas, penulis ingin merumuskan masalah yaitu Bagaimana pertumbuhan dari negara sekunder? sesuai dengan rumusan masalah 
yang telah penulis sampaikan, maka tujuan dari makalah ini adalah untuk mengetahui bagaimana pertumbuhan dari negara sekunder tersebut.

\section{B. PEMBAHASAN}

Terjadinya negara secara sekunder merupakan sebuah teori yang membahas tentang terjadinya negara yang dihubungkan dengan negara-negara yang telah ada sebelumnya. Namun karena adanya revolusi, intervensi, dan penaklukan, timbul negara yang menggantikan negara yang telah ada tersebut. Kenyataannya terjadinya negara secara sekunder tidak dapat dipungkiri meskipun cara terbentuknya kadang tidak sah menurut hukum. Jadi yang paling penting dalam pembahasan terjadinya negara secara sekunder ini adalah masalah pengakuan atau Erkening oleh negara lain. Mengenai masalah pengakuan atau Erkening ini ada tiga macam:

1. Pengakuan de facto (sementara), yaitu pengakuan yang bersifat sementara terhadap munculnya atau terbentuknya negara baru. Pengakuan ini bersifat sementara karena negara baru yang terbentuk tersebut masih dipertanyakan apakah telah melalui prosedur hokum. Pengakuan de facto ini bisa meningkat pada pengakuan de jure apabila prosedur munculnya negara baru tersebut sesuai dengan prosedur hokum yang sebenarnya.

2. Pengakuan de jure (pengakuan yuridis), yaitu pengakuan seluas-luasnya terhadap munculnya suatu negara, karena terbentuknya negara baru harus berdasarkan yuridis atau berdasarkan hukum.

3. Pengakuan atas pemerintahan de facto, merupakan suatu pengakuan yang hanya pada pemerintahan suatu negara. Unsur-unsur lain seperti bangsa dan 
wilayah tidak diakui. Istilah ini diciptakan oleh sarjana Belana bernama Van Haller pada saat proklamasi kemerdekaan Indonesia.

Terdapat dua macam pendekatan terjadinya Negara secara sekunder, yaitu pendekatan faktual dan pendekatan teoritis:

1. Pendekatan Faktual

Pendekatan faktual merupakan pendekatan yang berdasarkan pada kenyataan yang benar-benar terjadi dan diungkap di dalam sejarah. Terdapat beberapa macam pendekatan faktual, yaitu sebagai berikut:

a) Proklamasi

Terjadi saat penduduk pribumi dari suatu wilayah yang diduduki oleh bangsa lain mengadakan perlawanan (perjuangan) sehingga dapat merebut kembali wilayahnya dan menyatakan kemerdekaan. Sebaga contoh Indonesia merdeka dari Belanda dan Jepang pada tanggal 17 Agustus 1945

b) Separatis (pemisahan)

Suatu wilayah negara yang memisahkan diri dari negara yang semula menguasainya kemudian menyatakan kemerdekaan / memisahkan diri. Sebagai contohnya Belgia memisahkan diri dari Belanda pada tahun 1939 dan menyatakan kemerdekaan.

c) Anexatie (penguasaan/pencaplokan)

Suatu negara berdiri di suatu wilayah yang dikuasai bangsa lain (diwilayah negara lain) tanpa reaksi / perlawanan yang memadai dari pendudukan setempat. Sebagai contohnya negara Israel terbentuk dengan mencaplok daerah Palestina, Suriah, Yordania, dan Mesir. Penaklukan suatu wilayah yang memungkinkan 
pendirian suatu negara di wilayah itu setelah 30 tahun tanpa reaksi yang memadai dari penduduk setempat.

d) Innovation (pembentukan baru)

Suatu negara baru muncul di atas suatu negara yang pecah karena suatu hal dan kemudian lenyap. Sebagai contohnya negara Colombia yang pecah dan lenyap kemudian diwilayah tersebut muncul negara baru, yaitu Venezuela dan Columbia baru.

e) Acessie (penairkan)

Bertambahnya tanah dari lumpur yang mengeras di kuala sungai (atau daratan yang timbul dari dasar laut) dan menjadi wilayah yang dapat dihuni manusia sehingga suatu ketika telah memenuhi unsur-unsur terbentuknya negara. Sebagai contohnya Mesir yang terbentuk dari delta Sungai Nil.

f) Cessie ( penyerahan)

Terjadi saat sebuah wilayah diserahkan kepada negara lain atas suatu perjanjian tertentu. Sebagai contohnya Wilayah Sleeswijk diserahkan oleh Austria kepada Prusia (Jerman), karena ada perjanjian bahwa negara yang kalah perang harus memberikan negara yang dikuasainya kepada negara yang menang. Austria adalah salah satu negara yang kalah dalam Perang Dunia I.

g) Fusi (peleburan)

Terjadi ketika negara-negara kecil mendiami sebuah wilayah, mengadakan perjanjian / kesepakatan untuk saling melebur menjadi sebuah negara baru atau dapat dikatakan suatu penggabungan dua atau lebih Negara menjadi Negara baru. 
Sebagai contohnya terbentuknya Federasi negara Jerman pada tahun 1871, yaitu Jerman Barat-Jerman Timur.

h) Occupatie (pendudukan)

Terjadi ketika suatu wilayah yang tidak bertuan dan belum dikuasai, kemudian diduduki dan dikuasi oleh suku atau kelompok tertentu dan didirikan negara diwilayah itu. Sebagai contohnya Liberia adalah daerah kosong yang dijadikan negara oleh para budak Negro yang dimerdekakan oleh Amerika. Liberia dimerdekakan pada tahun 1847.

i) Pendudukan Atas Wilayah yang Belum Ada Pemerintahan Sebelumnya

Pendudukan ini terjadi terhadap wilayah yang ada penduduknya, namun tidak berpemerintahan. Sebagai contohnya Australia merupakan daerah baru yang ditemukan Inggris meskipun di sana terdapat suku Aborigin. Daerah Australia kemudian dibuat koloni-koloni di mana penduduknya didatangkan dari daratan Eropa. Selanjutnya Australia dimerdekakan tahun 1901.

\section{Pendekatan Teoritis}

Pendekatan teoritis merupakan pendekatan yang mempelajari tentang asal mula dari sebuah negara yang berdasarkan atas teori-teori dan hipotesis ilmu pengetahuan. Terdapat beberapa macam pendekatan teoritis, yaitu sebagai berikut:

a) Teori Ketuhanan

Teori ini memiliki pengertian bahwa segala sesuatu terjadi atas kehendak Tuhan. Demikian juga negara terjadi atas kehendak Tuhan. Bukti nyata teori ini 
dapat dilihat dalam kalimat "by the Greece of God" pada undang-undang dasar suatu negara, seperti Pembukaan UUD 1945.

Latar belakang munculnya teori ini karena Tuhanlah yang menciptakan alam dan segala isinya. Negara atau raja hanya memerintah atas dasar kehendak Tuhan. Oleh karena itu, mereka memiliki hak luar biasa dan tidak boleh dibantah. Hal ini seperti ajaran Polytheisme. Penganut teori ini adalah F.Y. Stahl, Kranenburg, Thomas Aquino, Haller, dan Agustinus.

b) Teori Perjanjian

Menurut teori ini, terjadinya negara karena adanya perjanjian masyarakat. Semua warga mengadakan perjanjian untuk mendirikan suatu organisasi yang melindungi dan menjamin kelangsungan hidup bersama. Negara terjadi sebagai hasil perjanjian antarmanusia/individu, di mana manusia berada dalam dua keadaan, yaitu keadaan sebelum bernegara dan keadaan setelah bernegara. Negara pada dasarnya adalah wujud perjanjian dari masyarakat sebelum bernegara untuk kemudian menjadi masyarakat bernegara. Penganut teori ini adalah ThomasHobbes, John Locke, J.J. Rousseau, dan Montesquieu.

c) Teori Kekuasaan

Teori ini menyatakan bahwa negara terjadi atas dasar kekuasaan. Kekuasaan berarti perjuangan hidup yang terkuat memaksakan kemauannya kepada yang lemah. Teori terjadinya negara menurut teori ini dikelompokkan menjadi dua, yaitu kekuasaan fisik dan kekuasaan ekonomi.Penganut teori ini adalah Harold J. Laski, Leon Duguit, Karl Marx, Oppenheiner, dan Koelikles. 
d) Teori Kedaulatan

Berdasarkan teori ini, terjadinya negara adalah sebagai berikut.

1) Teori kedaulatan negara, yaitu negara memegang kekuasaan tertinggi untuk menciptakan hukum demi mengatur kepentingan rakyat. Penganut teori ini adalah Paul Laband dan Jellinek.

2) Teori kedaulatan hukum, yaitu hukum memegang peranan tertinggi dan kedudukannya lebih tinggi dari negara. Penganut teori ini adalah Krabbe.

e) Teori Hukum Alam

Menurut teori ini, terjadinya negara karena kekuasaan alam yang berlaku setiap waktu dan tempat, serta bersifat universal dan tidak berubah. Menurut teori hukum alam, terjadinya negara adalah sesuatu yang alamiah terjadi. Bahwa segala sesuatu itu berjalan menurut hukum alam, yaitu mulai dari lahir, berkembang, mencapai puncaknya, layu dan akhirnya mati. Negara terjadi secara alamiah dengan bersumber dari manusia sebagai makhluk sosial yang memiliki kecenderungan berkumpul dan saling berhubungan untuk mencapai kebutuhan hidupnya. Penganut teori ini adalah Plato, Aristoteles, Agustinus, dan Thomas Aquino.

Dipandang dari sisi terjadinya sebuah negara yang dikemukakan oleh para pakar sejarawan maupun kenegaraan, bahwa negara indonesia terjadi secara sekunder. Dimana dapat dikatakan bahwa negara Indonesia muncul karena telah ada negara sebelumnya, yaitu negara Belanda dan Jepang. Negara Kesatuan Republik Indonesia lahir melalui 
suatu revolusi pada tanggal 17 Agustus 1945. Kelahiran Indonesia ini secara otomatis mengakhiri pemerintahan Hindia Belanda (Nederlans Belanda) di Indonesia.

Sejak diproklamasikannya kemerdekaan Indonesia, bangsa Indonesia dengan resmi telah menyatakan kepada negara lain bahwa Negara Indonesia telah merdeka. Merdeka memiliki arti bebas untuk menentukan nasib bangsa dan tanah air dalam semua bidang. Dimana proklamasi kemerdekaan pada tanggal 17 Agustus 1945 merupakan sumber hukum bagi pembentukan kesatuan Republik Indonesia.

Dengan berdirinya Negara Republik menandakan telah terputusnya ikatan dengan ketatanegaraan yang sebelumnya, baik ketatanegaraan pemerintah Belanda maupun pemerintah Jepang. Bisa dikatakan bahwa garis pemisah antara ketatanegaraan colonial dengan ketatanegaraan Republik Indonesia adalah proklamasi kemerdekaan.

\section{PENUTUP}

Terjadinya negara menurut para pakar sejarawan dan kenegaraan dibedakan menjadi dua macam, yaitu primer dan sekunder. Negara Indonesia merupakan negara yang terjadi secara sekunder dimana Indonesia muncul karena telah ada negara sebelumnya, yaitu negara Belanda dan negara Jepang.

Terjadinya negara secara sekunder berdasarkan pendekatan faktual, terdiri dari proklamasi, separatis (pemisahan), anexatie (penguasaan/pencaplokan), innovation (pembentukan baru), acessie (penarikan), cessie (penyerahan), fusi (peleburan), occupatie (pendudukan) serta pendudukan di wilayah yang belum terdapat kepemerintahan sebelumnya. Berdasarkan sudut pandang dari pendekatan faktual negara Indonesia terjadi secara proklamasi, dimana ketika penduduk pribumi dari sebuah wilayah yang diduduki 
oleh bangsa lain melakukan sebuah perjuangan sehingga berhasil merebut wilayahnya kembali dan akhirnya menyatakan kemerdekaannya.

Tejadinya negara secara sekunder berdasarkan pendekatan teoritis, dibagi kedalam lima teori, diantaranya adalah Teori Ketuhanan, Teori Perjanjian, Teori Kekuasaan, Teori Kedaulatan dan Teori Hukum Alam. Apabila kita melihat dari sudut pandang pendekatan teoritis maka terjadinya negara Indonesia termasuk kedalam teori ketuhanan. Dimana menurut teori ini didasarkan pada sebuah kepercayaan bahwa segala sesuatu yang terjadi atas kehendak Tuhan. Ini bisa dilihat pada UUD -nya "By the Grace of God" (Atas berkat Tuhan yang Maha Esa). Hal ini sesuai dengan Negara Indonesia, dimana dalam UUD Alinea ke-3 “Atas berkat Rahmat Tuhan Yang Maha Esa ...”. 


\section{DAFTAR PUSTAKA}

Darmini Roza dan Laurensius Arliman S Peran Pemerintah Daerah Di Dalam Melindungi Hak Anak Di Indonesia, Masalah-Masalah Hukum, Volume 47, Nomor 1, 2018.

Laurensius Arliman S, Komnas HAM dan Perlindungan Anak Pelaku Tindak Pidana, Deepublish, Yogyakarta, 2015.

Laurensius Arliman S, Penguatan Perlindungan Anak Dari Tindakan Human Trafficking Di Daerah Perbatasan Indonesia, Jurnal Selat, Volume 4, Nomor 1, 2016.

Laurensius Arliman S, Problematika Dan Solusi Pemenuhan Perlindungan Hak Anak Sebagai Tersangka Tindak Pidana Di Satlantas Polresta Pariaman, Justicia Islamica, Volume 13, Nomor 2, 2016.

Laurensius Arliman S, Pelaksanaan Perlindungan Anak Yang Tereksploitasi Secara Ekonomi Oleh Pemerintah Kota Padang, Veritas et Justitia, Volume 2, Nomor 1, 2016.

Laurensius Arliman S, Kedudukan Ketetapan MPR Dalam Hierarki Peraturan PerundangUndangan Di Indonesia, Lex Jurnalica, Volume 13, Nomor 3, 2016.

Laurensius Arliman S, Komnas Perempuan Sebagai State Auxialiary Bodies Dalam Penegakan Ham Perempuan Indonesia, Justicia Islamica, Volume 14, Nomor 2, 2017.

Laurensius Arliman S, Peranan Pers Untuk Mewujudkan Perlindungan Anak Berkelanjutan Di Indonesia, Jurnal Ilmu Hukum Tambun Bungai, Volume 2, Nomor 2, 2017. 
Laurensius Arliman S, Mewujudkan Penegakan Hukum Yang Baik Untuk Mewujudkan Indonesia Sebagai Negara Hukum, Jurnal Hukum Doctrinal, Volume 2, Nomor 2, 2017.

Laurensius Arliman S, Participation Non-Governmental Organization In Protecting Child Rights In The Area Of Social Conflict, The 1st Ushuluddin and Islamic Thought International Conference (Usicon), Volume 1, 2017.

Laurensius Arliman S, Partisipasi Masyarakat Dalam Pembentukan Perundang-Undangan Untuk Mewujudkan Negara Kesejahteraan Indonesia, Jurnal Politik Pemerintahan Dharma Praja, Volume 10, Nomor 1, 2017, https://doi.org/10.33701/jppdp.v10i1.379.

Laurensius Arliman S, Peran Komisi Perlindungan Anak Indonesia Untuk Mewujudkan Perlindungan Anak, Jurnal Respublica Volume 17, Nomor 2, 2018.

Laurensius Arliman S, Menjerat Pelaku Penyuruh Pengrusakan Barang Milik Orang Lain Dengan Mempertimbangkan Asas Fungsi Sosial, Jurnal Gagasan Hukum, Volume 1, Nomor 1, 2019.

Laurensius Arliman S, Ilmu Perundang-Undangan Yang Baik Untuk Negara Indonesia, Deepublish, Yogyakarta, 2019.

Laurensius Arliman S, Isdal Veri, Gustiwarni, Elfitrayenti, Ade Sakurawati, Yasri, Pengaruh Karakteristik Individu, Perlindungan Hak Perempuan Terhadap Kualitas Pelayanan Komnas Perempuan Dengan Kompetensi Sumber Daya Manusia Sebagai Variabel Mediasi, Jurnal Menara Ekonomi: Penelitian dan Kajian Ilmiah Bidang Ekonomi, Volume 6, Nomor 2, 2020.

Laurensius Arliman S, Pendidikan Kewarganegaraan, Deepublish, Yogyakarta, 2020. 
Laurensius Arliman S, Makna Keuangan Negara Dalam Pasal Pasal 23 E Undang-Undang Dasar 1945, Jurnal Lex Librum, Volume 6, Nomor 2 Juni 2020, http://dx.doi.org/10.46839/1ljih.v6i2.151.

Laurensius Arliman S, Kedudukan Lembaga Negara Independen Di Indonesia Untuk Mencapai Tujuan Negara Hukum, Kertha Semaya Journal Ilmu Hukum, Volume 8, Nomor 7, 2020.

Laurensius Arliman S, Pelaksanaan Assesment Oleh Polres Kepulauan Mentawai Sebagai Bentuk Pelaksanaan Rehabilitasi Bagi Pecandu Dan Korban Penyalahgunaan Narkotika, Jurnal Muhakkamah, Volume 5, Nomor 1, 2020.

Laurensius Arliman S, Aswandi Aswandi, Firgi Nurdiansyah, Laxmy Defilah, Nova Sari Yudistia, Ni Putu Eka, Viona Putri, Zakia Zakia, Ernita Arief, Prinsip, Mekanisme Dan Bentuk Pelayanan Informasi Kepada Publik Oleh Direktorat Jenderal Pajak, Volume 17, No Nomor, 2020.

Larensius Arliman S, Koordinasi PT. Pegadaian (Persero) Dengan Direktorat Reserse Narkoba Polda Sumbar Dalam Penimbangan Barang Bukti Penyalahgunaan Narkotika, UIR Law Review, Volume 4, Nomor 2, 2020, https://doi.org/10.25299/uirlrev.2020.vol4(1).3779.

Laurensius Arliman S, Tantangan Pendidikan Kewarganegaraan Pada Revolusi 4.0, Ensiklopedia Sosial Review, Volume 2, Nomor 3, 2020.

Muhammad Afif dan Laurensius Arliman S, Protection Of Children's Rights Of The Islamic And Constitutional Law Perspective Of The Republic Of Indonesia, Proceeding: Internasional Conference On Humanity, Law And Sharia (Ichlash), Volume 1, Nomor 2, 2020. 
Otong Rosadi danLaurensius Arliman S, Urgensi Pengaturan Badan Pembinaan Idelogi Pancasila Berdasarkan Undang-Undang Sebagai State Auxiliary Bodies yang Merawat Pancasila dalam Perspektif Hak Asasi Manusia, Prosiding Konferensi Nasional Hak Asasi Manusia, Kebudayaan dan Tujuan Pembangunan Berkelanjutan Indonesia pada Masa Pandemi Covid-19: Tantangan untuk Keilmuan Hukum dan Sosial Volume 1, Universitas Pancasila, Jakarta, 2020. 